\title{
A MULTIKULTURALIZMUS HATÁSA AZ ÉPÍTÉSZETRE
}

\section{MULTICULTURAL EFFECTS IN THE ARCHITECTURE}

\author{
Juhász Hajnalka, ${ }^{1}$ Kósa Balázs, ${ }^{2}$ Molnár Tamás ${ }^{3}$ \\ ${ }^{1}$ Pécsi Tudományegyetem, Müszaki és Informatikai Kar, Breuer Marcell Doktori Iskola, Pécs, Magyarország, \\ hjuhasz91@gmail.com \\ ${ }_{2}^{2}$ Pécsi Tudományegyetem, Múszaki és Informatikai Kar, Belsőépítészeti Alkalmazott és Kreatív Design \\ Tanszék, Pécs, Magyarország, kosa.balazs.84@gmail.com \\ ${ }^{3}$ Pécsi Tudományegyetem, Müszaki és Informatikai Kar, Vizuális Ismeretek Tanszék, Pécs, Magyarország, \\ tmolnar@mik.pte.hu
}

\begin{abstract}
Many scientific field working about the topic of the multiculturalism which slowly became the most common aspect of the $21^{\text {th }}$ century. When we examine the culturally mixed societies, the demands of different habits are compared, and it is one of the main points what the architecture continuously trying to react. In our research we examine the city of Pécs and it's university, to create a grounded designing concept for a new multi-belief space.
\end{abstract}

Keywords: multiculturalism, multi-belief spaces, architecture, Pécs.

\section{Összefoglalás}

Számos tudományág szakterülete foglalkozik a multikulturalizmus témakörével, ami lassan a XXI. század legtermészetesebb velejárója. A kulturálisan vegyes társadalmak vizsgálatakor összehasonlításra kerülnek az eltérő szokásokból adódó igények, melyekre igyekszik az építészet is folyamatosan reagálni, az új helyzetekből következő elvárásoknak eleget tenni. Tanulmányunkban Pécs városa és egyetemének helyzetét vizsgáljuk, egy új szakrális tér megalkotásának koncepciójához.

Kulcsszavak: multikulturalizmus, több-vallású terek, építészet, Pécs.

\section{Bevezető}

\section{1. Állásfoglalás}

Napjainkban, számos olyan hatást rögzíthetünk, ami a hagyományos értelemben vett határainkon átível, köszönhetően a sok tekintetben felgyorsult információáramlásnak. Ezáltal helyhez kötöttségünk lazul, szélesebb az egyén elé táruló perspektíva, ami a kezdetben legfőképp vallási, majd nemzeti alapon rendeződő társadalmak vegyülésének enged teret. Az egyre sűrűbben alkalmazott multikulturalizmus fogalma számos tudományterületben megjelenik, így a természetes és mesterséges környezetünk alakítását illetően, az építészetben is.
A megelőző történeti korokban a kultúrák keveredésének két legfőbb esete volt, a megszálló hatalmak elnyomó politikájából következő, és a különféle betelepülések és mesterséges betelepítések eredményeként létrejött vegyes közegek. Az így kialakult helyzetek során a többségi és kisebbségi kultúrák számos esetben, nagyobb összetűzésektől mentesen, alkalmazkodva müködtek egymás mellett, esetenként átvéve a műszaki és formai megoldásokat egymástól.

Ezt szem előtt tartva, a továbbiakban tárgyalt multikulturalizmus tehát sem a többségi kultúra teljes dominanciáját, sem pedig a különféle kulturális tradíciók egybeolvasztását nem tartja megoldásnak, hanem abból indul ki, hogy minden csoport őrizze meg és ápolja zavartalanul a maga sa- 
ját kultúráját. A tanulmányunkban a kulturálisan vegyes településeket és városokat vizsgáljuk, fókuszba helyezve a kialakult építészeti formanyelvek fejlődésének irányát, a valós funkciókat és igényeket összevetve. Továbbá előtérbe helyezve egy adott épület koncepcionális kidolgozását több kultúra által érintett környezetben.

\section{Pécs helyzete}

\subsection{Történeti alap}

A történelem során egy település felértékelődése a vallási, gazdasági és stratégiai szempontok legalább egyikének teljesülése szerint ment végbe. Az így fontossá vált csoportosulásokra jellemző volt, hogy idővel több kultúra élt egymás mellett, amelyek saját építészeti formanyelvük alkalmazásával terjeszkedtek tovább. Mindezt tisztán mutatja a mai Dél-dunántúli régió központjává vált Pécs és vonzáskörzete is, a kulturális sajátosságokat hordozó építészeti alkotásokkal vagy rosszabb esetben azok maradványaival. Az örökségvédelem tekintetében ilyen építmények voltak például az ókeresztény temetkezési szokásokat megörökítő sírkamrák, ugyanúgy, mint a török emlékek (dzsámik, fürdő romok, a türbe, stb.), melyek annak ellenére, hogy egy hódító hatalom építészetét tükrözik, mára mégis a város jelképévé váltak és gazdagítják annak épített környezetét. Az említett műemlékek nemzetközi szinten is bejegyzett, a világörökség részévé nyilvánított értékek. Számos régészeti, történeti kutatás mellett, feltárásuk és helyzetbe hozásuk, kortárs építészeti és müszaki megoldásokkal támogatott program volt.

\begin{tabular}{|l|c|c|c|c|}
\hline év & $\begin{array}{c}\text { PTE MIK } \\
\text { össz. }\end{array}$ & magyar & külföldi & $\begin{array}{c}\text { külföldi } \\
\text { \% }\end{array}$ \\
\hline 2013 & 2851 & 2799 & 52 & 1,82 \\
\hline 2014 & 2466 & 2374 & 92 & 3,73 \\
\hline 2015 & 2356 & 2179 & 174 & 7,39 \\
\hline 2016 & 2302 & 2047 & 266 & 11,08 \\
\hline 2017 & 2383 & 2018 & 365 & 15,32 \\
\hline
\end{tabular}

2. ábra. Az elmúlt öt év hallgatói eloszlása a Pécsi Tudományegyetem Müszaki és Informatikai Karán (a táblázat készültekor a 2018. évi adatok még nem álltak rendelkezésünkre).

\subsection{Jelenkori adottság}

Pécsen a kultúrák találkozásának másik pontja többek között a felsőoktatásban mutatkozik meg. A város egyeteme, a Pécsi Tudományegyetem, számos külkapcsolattal rendelkezik, a Múszaki és Informatikai Kar esetében ez 24 ország, összesen 56 társintézményét jelenti.

Tehát, a történeti múlton túl, az elmúlt évtizedekben az építészeti tervezés kérdései közt hangsúlyt kaptak a különböző kultúrák találkozásának helyet adó épületek is. Pécsi vonatkozásban ilyenek, a teljesség igénye nélkül, az egyetemi karok épületei és a hozzájuk kapcsolódó kutatóintézetek.

Az utóbbi tíz évben folyamatosan növekvő külföldi hallgatói létszám tükrében jogosan merül fel a gondolat, miszerint az eltérő területekről érkező egyetemisták saját kulturális szokásai miként érvényesülhetnek az idegen környezetben. A legkézenfekvőbb ilyen tekintetben a vallásgyakorlás kérdése.

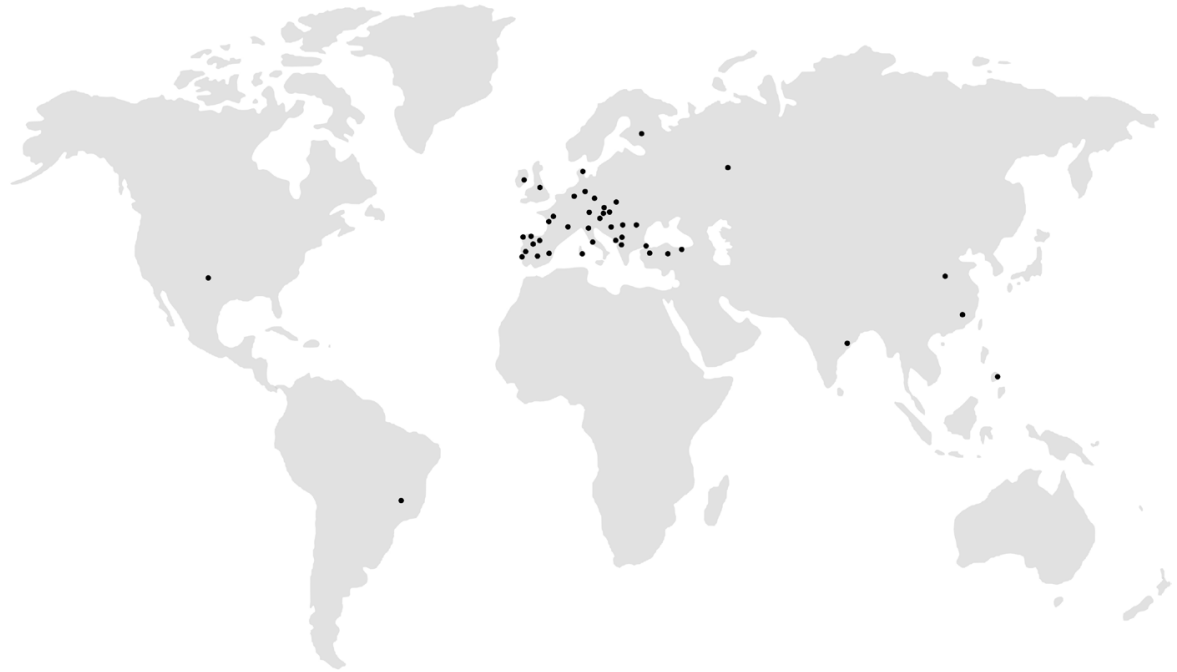

1. ábra. Pécsi Tudományegyetem Müszaki és Informatikai Kar társintézményeinek eloszlása világviszonylatban 24 országot érint 


\begin{tabular}{|l|c|}
\hline \multicolumn{2}{|c|}{ Pécsi Tudományegyetem } \\
\hline Ország & Külföldi halgatók \\
\hline Németország & 691 \\
\hline Norvégia & 267 \\
\hline Irán & 200 \\
\hline Kina & 125 \\
\hline Spanyolorszás & 105 \\
\hline Jordánia & 90 \\
\hline Koreai Köztársaság & 87 \\
\hline Brazilia & 60 \\
\hline Törökország & 51 \\
\hline Svédország & 49 \\
\hline
\end{tabular}

\section{Következtetések, összegzés}

Kutatásunk eredményeként megállapítható, hogy egy város kulturális meghatározása nem egyszerüsíthető le egyetlen csoportra a többség (adott esetben az ország) által képviselt eszmék szerint. Mindazonáltal az emberek hozzáállása egy idegen kultúrához, eltérő mintát mutat egy olyan társulásban, ahol a vegyes kulturális közeg akár már a történeti időkre is visszavezetve jelen volt, mint Pécs esetében.

Jelenkori helyzetünk, a globalizációval kapcsolatba hozhatóan, egyre több olyan helyzetet teremt, ahol a multikulturális hatások általánossá válnak és eredményeik leképzése tárgyiasul az egyes tudományterületeken, ahogyan az építészetben is.

A dolgozat a Pécsi Tudományegyetem kulturálisan vegyes hallgatói összetételét alapul véve fogalmazza meg az igényt egy olyan több vallás szükségleteinek megfelelő „kápolnára” mely teret biztosíthat az egyéni vallásgyakorlásra illetve a magukat külön valláshoz nem soroló emberek számára a csendes elmélyülésre, gondolkodásra. Tanulmányunk tehát a koncepcionálisan megalapozott tervezési folyamat első lépéseként készült, egy jövőben remélhetően megvalósításra kerülő, vallás tekintetében semleges, kisléptékű szakrális tér kialakításához.

\section{Szakirodalmi hivatkozások}

[1] Majtényi Balázs: A nemzetállam új ruhája. Multikulturalizmus Magyarországon. Gondolat Kiadó, Budapest, 2007. 23-39.

[2] Francisco Díez de Velasco: Multi-belief/Multi-faith Spaces: Theoretical Proposals for a Neutral and Operational Design. RECODE - Responding to Complex Diversity in Europe and Canada. 2014. Online Working Paper 26. (letöltve: 2019.02.15.). http://www.recode.info/wp-content/uploads/2014/01/FINAL-26-D\%C3\%ADez-de-Velasco_fin.pdf

[3] Francisco Colom Gonzalez \& Gianni D'Amato (Eds.): Multi-belief/Multi-faith Spaces: Theoretical Proposals for a Neutral and Operational Design. In: Multireligious Society: Dealing with Religious Diversity in Theory and Practice. Ashgate/ Routledge, 2017. 236-250. (letöltve: 2019. jan. 18.) https://www.researchgate.net/publication/313930537_Multi-beliefMulti-faith_Spaces_ Theoretical_Proposals_for_a_Neutral_and_Operational_Design_en_Francisco_Co-lom_Gonzalez_Gianni_D'Amato_Eds_Multireligious_Society_ Dealing_with_Religious_Diversity_in_Theo

[4] Pécsi Tudományegyetem: Tények/adatok/ statisztikák. letöltve: 2019. január 18.)

https://pte.hu/tenyek_adatok/statisztikak 
[5] Wusching Á. T.: A nemzetközi hallgatók tanulmányi célú mobilitásának jellegzetességei Pécs és Debrecen példáján. Tér és Társadalom, 31/2. (2017). 69-72.

https://doi.org/10.17649/TET.31.2.2828

[6] Egedy G.: A multikulturalizmus dilemmái: Nagy-Britannia példája. 2006. (letöltve: 2019. feb.

09.)

https://polgariszemle.hu/archivum/23-2006-junius-2-evfolyam-6-szam/106-a-multikulturalizmus-dilemmai-nagy-britannia-peldaja\#note2 